\title{
Building new approaches to thinking about vocational education and training and development: Policy, theory and evidence
}

\author{
Simon McGrath
}

This is a particularly pertinent moment to be writing about the current state and likely future directions of vocational education and training in developing countries. This paper should be published sometime between two significant moments in the international debate about VET for development. In May 2012, the Third International Congress on Technical and Vocational Education and Training will have taken place in Shanghai, accompanied by a World Report, whilst in September 2012 the latest Global Monitoring Report will be on Skills. As McGrath notes in the next article, these can be seen as part of a larger wave of international policy work about VET.

There is also an important further policy moment beginning as attention turns to the time "beyond 2015" when the millennium development goals "need" to be replaced with a new development vision and goals. VET suffered indirectly from the MDG process through the narrowing of the education agenda to primary schooling. That both the successes and failures of the education MDGs have contributed to the recent reawakening of VET may suggest that there is a moment now to make a case for VET's greater presence in a new development vision. Moreover, this may resonate well with voices that argue that both work and developmental capacity are areas that need to be emphasised in a "Beyond 2015" agenda.

What draws this special issue together is a concern that there is a triple moment of challenge and opportunity facing those of us interested in issues of VET for development. Alongside the policy moment outlined above, there is also a theoretical moment during which there is a real possibility of significantly advancing the sophistication of our accounts of what is going on in VET for development due to recent moves in development theory and the moment of reflection provided by the World Congress and its related Report. Both of these two moments are intertwined with a multi-faceted evidential moment. First, this reflects the rise of new and, I will argue, dangerous approaches to thinking about evidence, which are increasingly infecting this field and others. Second, the policy moment does legitimately raise questions about the parlous state of VET data and evidence internationally, as McGrath and Lugg explore in their contribution to this special issue. Third, the theoretical moment opens up possibilities of thinking about epistemology and methodology in potentially fruitful new ways, a point made both by McGrath and Lugg, and Powell. The very weaknesses in these three areas offer a major window of opportunity for new thinking about VET and its theoretical and practical relationships with development.

\section{Beyond the borrowing of a policy toolkit}

A strong theme of several papers in this special issue is the notion of policy toolkits. From searches of the web and academic literature, it is clear that toolkits are part of the wider "what works" agenda that McGrath and Lugg critique. A google search whilst writing this paper revealed that the phrase "policy toolkit" generated 181000 hits. Strikingly the first page of these hits illustrates the pervasiveness of this notion, at least in the United Kingdom. 


\section{Table 1}

Top 10 hits on "policy toolkit"

1. The Office of the First Minister, Northern Ireland

2. London museums

3. World Hepatitis alliance

4. Public health observatories

5. Migration Scotland

6. The Further Education Excellence Gateway

7. Collections link (museums)

8. Leeds school meals

9. OECD consumer policy

10. The Mother's Union (social policy)

Source: Google 28/02/12.

Although there are hints of criticism of the metaphor of toolkits that go back at least to Owens and Connell, 2001, the academic literature that uses this notion is almost uniformly uncritical about the concept and concerned with developing or improving toolkits, across a range of social science, engineering and health disciplines.

Understanding this epidemic is beyond the scope of this paper, but McGrath (2010) suggests that the VET toolkit should best seen within a broader story of the rise of new public management, governmentality and performativity that links in turn to analyses of the current phase of globalised capitalism.

I am using the metaphor here to reflect primarily on a set of policies that have "travelled" across the globe into many national VET systems and which reflect the standard policy options that most policymakers, consultants and international agencies are likely to draw upon when developing national models. As McGrath notes, the key tools in the kit are:

_ systemic (and sometimes sectoral) governance reforms;

- qualifications frameworks;

- quality assurance systems;

- new funding mechanisms; and

_ managed autonomy for public providers.

This approach draws most heavily on an Anglo-Scottish model of vocational educational reform, notwithstanding the powerful criticisms this model has engendered both from academics and from a series of policy commissions. When this policy has travelled, it has done so within the broader moment of globalisation of course, but it has been divorced from its specific national contexts. This leads to a series of critiques that this special issue advances.

First, and most narrowly, it is argued that the toolkit assumes a level of national capacity, both in state and society, that simply is not available in most of the countries to which the toolkit is being applied. Even if the toolkit can work in theory, or in its home contexts, it cannot be expected to work in much more constrained circumstances.

Second, following on from the long-standing comparative 2010), it is possible to see the spread of the toolkit as a highly complex process. In part, it appears to be a case of the networked flow of a discourse that takes place without little conscious agency. However, it seems that it is far more than this and that agency is very present in both exporting and importing contexts. First, it is apparent that there has been active selling, both metaphorical and real, of key notions, especially national qualifications frameworks, by national and regional organisations that rely on policy and consultancy work for an important part of their income. This would include organisations such as the Scottish Qualifications Authority, the British Council and the European Training Foundation. Thus, the spread of these ideas again needs to be placed within a context of a particular phase 
of global development in which parastatal organisations have been encouraged to go "onto the market" and increasingly have sought to do this globally as well as locally.

However, it is important to avoid the impression that this is entirely a matter of selling as can happen in some writing about aid and its conditionalities. Whilst there may be little choice regarding VET reforms for countries desperate to join the European Union (if this remains highly attractive), for countries such as India and South Africa (as discussed particularly in King's and Akoojee's papers) there clearly is a large degree of local agency. Explicating the complex processes inherent in a country as powerful as India in adopting an "international best practice" that has no evidential basis (national qualifications frameworks) is an important item for a future research agenda for VET and development.

Third, there is a standard comparative education injunction that "context matters" (Crossley and Jarvis, 2001). In this case, this can be developed further by linking the conventional comparative education account with the approaches used in the critical political economy of skills tradition, as illustrated by Allais's paper, a point that I will expand upon shortly.

\section{Building beyond the narrow theoretical orthodoxy}

The critique of toolkits clearly is one of this special issue's theoretical arguments. However, a number of papers develop a deeper set of theoretical critiques of the current orthodoxy. McGrath draws upon the critiques of productivism made by Giddens (1994) and Anderson (2009), as well as human rights and human development approaches to argue that the current orthodoxy is based in too narrow an understanding of the world, including concerns about the gendered nature of work; the environmental unsustainability of current approaches to production; and its limiting of humanity to marketised consumption and production.

In the face of this impoverished theorisation, the authors in this special issue offer a range of possible theoretical resources for creative theorising about VET. Lim, Anderson and McGrath suggest that the sociology of the professions (and this would apply to the broader sociology of work) forms an important part of understanding how VET policies are developed, interpreted and resisted.

Moreover, they remind us of the salience, in contexts such as Malawi's, of reading VET debates through the lens of post-colonial cultures. A number of papers also draw on policy sociology traditions, often in potentially important cross-disciplinary ways, such as in Akoojee's use of boundary objects.

As already noted, Allais draws heavily on the critical political economy of skills tradition. This provides the crucial insight of locating skills policy debates within historical and geographic contexts to do with wider developmental dynamics. Although this approach has a strong comparative tradition in Europe, with important French, German and British strands (e.g., Maurice et al., 1986; Crouch and Streeck, 1997; Ashton and Green, 1996), and looks strongly at East Asia (Ashton and Green, 1996; Brown et al., 2001), it has not been much used in other regions, with the exception of South Africa (cf.,McGrath et al., 2004). There may be considerable merits in trying to expand such an approach to other Southern contexts, something that was beyond the scope of this special issue.

McGrath and Powell look into the broad human development and capabilities tradition for new insights into thinking about the VET-development relationship. Both suggest that human development approaches offer the possibility of advancing humanistic accounts that are far less reductive and universal than the productivist account. Powell in particular stresses the importance of understanding and engaging with the aspirations of those participating in VET. In drawing in part on the contributions to human development theorisation from Catholic Social Teaching, McGrath seeks to open up a 
fruitful new debate about the wider meanings of vocation and work. This echoes the German tradition of thinking about a Berufskonzept, a vocational philosophy, and offers potential engagement with broader philosophical accounts of VET and work, such as those of Winch $(1998,2000,2006)$, Rose (2004) and Sennett (2008, 2012). McGrath's paper also has the potential to build on the dialogue between international and comparative education and religion-in-development, started by the Comparative Education special issue on this topic of 2010.

The theoretical work done in this issue, however, must be seen as emergent and indicative. Its main functions are to critique the existing theory as unfit for purpose, and to begin new theorisations for a field that has been theoretically weak. In offering new theorisations, the intention of this special issue is to be deliberately divergent and to avoid both the absolute rejection of economistic insights into VET and development and the tendency of that approach to reject alternative accounts as unworthy of consideration. As I will develop further below, a stress on theoretical pluralism also implies a belief in methodological pluralism regarding VET for development.

Having acknowledged the emergent nature of our theoretical accounts, it is important to highlight some limitations that remain in these theorisations. Both in the existing toolkit approach and in our accounts, one important absence is a compelling theory of change. The toolkit cum productivist approach naively assumes that policies can be formulated based on universal theories and then unproblematically implemented. However, the main potential rival theory of VET policy, the political economy approach, also has a major weakness with regard to change. This account is very powerful in generating accounts of how skills systems have been enabled or constrained by social, cultural, political and economic dynamics within specific countries. However, it is far less convincing as, and generally avoids, an account of how practically deep-seated constraints and cultural barriers can be overcome. Indeed, where such accounts have emerged they are in large part overly optimistic blends of Post-Fordist inevitability and an assumption that others can imitate East Asian development states.

The attempt to bring human development and capabilities thinking to bear on VET for development is extremely new. Indeed, this special issue represents the most concerted engagement with this issue of which we are aware. As McGrath notes, capabilities work within education has concentrated heavily on schooling and universities, although Walker and McLean (2010); Walker and McLean's (2010; and Walker et al., 2009) recent development of work on professional capabilities is an obvious point of connection to VET work. Moreover, the capabilities approach has remained relatively weak on economics, production and work, notwithstanding Sen's parental influence. At present, it may be that the longer-standing Catholic variant of human development thinking is more potentially productive in this regard given the strong Catholic tradition of placing work at the heart of social life and individual identity (see McGrath's paper in this issue).

\section{Better understanding the possibilities and limitations of evidence}

I must reiterate the point that there is little or no evidence that the toolkit works. Indeed, one of the most striking features of the toolkit is that such criticism appears to be unhearable by its many advocates. This was strikingly shown when its most prominent element, NQFs, was the subject of a major international review by the International Labour Office (Allais, 2010). Although this report was subjected to appropriate peer scrutiny, including a two-day event that brought together researchers and staff from several qualifications authorities, its conclusion that there was no clear evidence that NQFs worked was subsequently publicly rejected by ILO's partners in the process, the European Training Foundation. Frequently in international fora I have attended, evidence for NQFs' success is taken as being simply that so many of them exist. 
This is the ideal type of what McGrath and Lugg were referring to in writing about "how policy trumps impact". Indeed, NQFs appear to be a matter of faith, masquerading as an example of "what works". Indeed, more generally, there is very little VET evidence or data at all. McGrath and Lugg's challenges in their work for SADC and UNESCO mirror wider challenges that UNESCO, for instance has faced in developing good international data on VET. As King (2011) has noted, worries about the inadequacies of data were part of arguments that effectively delayed a skills GMR.

Yet, as McGrath and Lugg outline, we are faced with a rising tide of positivistic certainty about evidence reflected in notions of what works, evidence-based practice, randomised control trials and international best practice. This has the potential to have highly perverse effects on what counts as educational evidence. It is likely to cause biases in educational policies, as is being seen in some recent international development agency policy consultations in which the educational terrain is delineated into places where evidence tells us to concentrate money and attention, and a terra incognita of topics for which there is "no evidence" and, thus, can be no policy. Of course, such an argument can collapse into the absurdities of never being able to innovate as innovation can never be contemplated without evidence that it already works.

As McGrath and Lugg remind us, there are severe methodological problems with these approaches, even from within the broad paradigm. They also caution us that to base education-for-development, let alone VET-for-development, on a sufficiently robust evidential basis within this paradigm would require an unconscionable diversion of resources to evaluation rather than implementation and innovation, given the scale of the evidential challenge. We also want to go beyond them in suggesting that evidencebased practice is often a discursive move aimed at overcoming opposition, building upon their reflections on the shallowness of evidence on which such best practices are often built. This point is made clear for us by the NQF example above, but also by the way that the toolkit is routinely talked about by many international policy actors.

Moreover, there are also serious epistemological and ideological issues with the evidential turn. In effect, this is an imperial project that is dismissive of many forms of knowledge and evidence that others would count as valid. It tends to silence voices of learners, educators and communities. Moreover, it also attempts to still academic voices. Thus in the British debate about evidence and educational research in the 1990s, an admixture of positivism and neoliberalism was mobilised against qualitative sociology, which was denigrated as partisanally leftist and divorced from practice. In contrast, one of the striking features of this special issue is the complex professional biographies of authors who have worked across government, consultancy and academia. Our joint concern is not so much with what works, but with how to makes things work better. It is not with establishing scientific and universal truths but in working and learning together for improvement in different times and places. Instead of the evidence-based monoculture, this special issue makes the case for a pluralism of methodologies and forms of data, evidence and knowledge. This must include better quantitative data and its more sophisticated analysis, but this needs to be placed alongside ways of hearing the voices of learners and professionals, and analytical tools that are capable of locating VET in contexts of time and space.

\section{Noting some silences in this special issue}

We must acknowledge the lack of economists' voices in this special issue. This reflects both a desire to talk back to the orthodoxy and a failure of engagement on both sides. It is important to remember that economic accounts of VET are a vital element of the overall picture and matters such as efficiency and effectiveness do need to be part of an overall account of VET for development. Our intention, however, is to go beyond established positions. Similarly, there is nothing of the anthropological-psychological tradition of authors such as Lave (2011); Lave (2011; and Rogoff and Lave, 1984), which has done important work in constructing an account of vocational learning in 
developing countries, particularly as it occurs in traditional apprenticeship systems and in the informal economy more generally.

The question of what counts as VET or whether this is indeed a useful concept is also largely side-stepped by this special issue, apart from some brief comments in McGrath, and McGrath and Lugg. As the World Report on TVET (UNESCO, 2012) makes clear this is a very challenging issue. We have used VET largely as a convenience, it being a widely accepted term and somewhat more elegant than TVET, in which the first " $t$ " - for "technical" - appears increasingly redundant. VET also serves in part as a halfway house, a terminological compromise, between vocational education, which even more strongly implies formal institutions dominated by a Ministry of Education, and skills development, more redolent of the workplace and the power of a Ministry of Labour. However, we are mindful that what we are talking about is far more complex than what it has been possible to represent across these papers.

What the papers do give some sight of is professional education (Lim, Anderson and McGrath); industrial training (most obviously in Akoojee); NGO provision of second or only chance training for marginalised youth (Hilal); and "regular" public vocational education and training (Powell). However, as King notes most clearly, there are hundreds of millions who work outside these systems. In his Indian case, it seems likely that their precarity is reflected in little vocational learning, of whatever formality. However, his earlier work from Africa (e.g. 1977 and 1996), along with the strand of research represented by Lave above, reminds us of the potential importance of informal work as a site of vocational learning. In this particular special issue, we lack accounts that update that work or which look at the growing hybridisation of academic and vocational learning in schools and universities or the continuation of historical processes of movement in the horizontal divisions between school, post-school and higher subsystems.

In spite of our best efforts, the authors in this special issue are drawn from an essentially Anglophone tradition of thinking about VET matters and this issue would be significantly different if it had have been possible to incorporate voices from other traditions more strongly

\section{Concluding comments}

We see this special issue as a staging post in developing a new way of thinking about and doing VET for development. It is part of a broader process in which our own organisations are involved in different ways. In particular, we want to draw attention briefly to the work of Norrag as co-convenors of the strand of the UKFIET International Conference on Education and Development from which this special issue evolved. Short early versions of the arguments of most of these papers appeared in Norrag News46 (Norrag, 2011) and many of the concerns, for instance about what works and international best practices, are to be found as recurrent themes across Norrag News issues (http://www.norrag.org). The conference strand and special issue were also coorganised by the City and Guilds Centre for Skills Development

(http://www.skillsdevelopment.org), which is a relatively new structure within one of the world's largest and oldest actors in the VET field. Like Norrag, CSD is concerned to build bridges between academic, policy and practitioner constituencies and to work across knowledge systems. Both organisations, and we as individual researchers, stress the need for multiple voices and approaches in thinking about VET and development.

I started by noting the timeliness of this special issue. VET is not just a backwater of the education system, populated by those who are unable to learn or teach successfully in more mainstream institutions and pathways. Rather, it is an integral part of our being as learners, workers and humans. Together with the contributors to this special issue, we are committed to improving VET policy, theory and evidence in order to support the expansion and enhancement of the freedoms and capabilities of all, but especially those 
who have been excluded from full participation in formal education. We hope that you will find something in the rest of this special issue that will provoke and/or inspire you to continue this project of developing a new way of thinking about and doing VET for development.

\section{References}

Akoojee, S., 2012. Skills for inclusive growth in South Africa: Promising tides amidst perilous waters. International Journal of Educational Development 32 (5), 674685.

Allais, S., 2010. The Implementation and Impact of National Qualifications Frameworks: Report of a Study in 16 Countries. ILO, Geneva.

Allais, S., 2012. Will skills save us? Rethinking the relationships between vocational education, skills development policies, and social policy in South Africa. International Journal of Educational Development 32 (5), 632-642.

Anderson, D., 2009. Productivism and ecologism: changing dis/courses in TVET. In: Fien, J., Maclean, R., Park, M.-G. (Eds.), Work, Learning and Sustainable Development. Springer, Dordrecht.

Ashton, D., Green, F., 1996. Education, Training and the Global Economy. Edward Elgar, Cheltenham.

Brown, P., Green, A., Lauder, H., 2001. High Skills. Oxford University Press, Oxford. Crossley, M., Jarvis, P., 2001. Context matters. Comparative Education 37, 405-408. Crouch, C., Streeck, W. (Eds.), 1997. Political Economy of Modern Capitalism, Sage, London.

Giddens, A., 1994. Beyond Left and Right. Polity, Cambridge.

Hilal, R., 2012. Vocational Education and Training for women and youth in Palestine: Poverty reduction and gender equality under occupation. International Journal of Educational Development 32 (5), 686-695.

King, K., 1977. The African Artisan. Heinemann, London.

King, K., 1996. Jua Kali Kenya. James Currey, Oxford.

King, K., 2011. Skills and Education for All from Jomtien (1990) to the GMR of 2012. A policy history. International Journal of Training Research 9 (1-2), 16-34.

King, K., 2012. The geopolitics and meanings of India's massive skills development ambitions. International Journal of Educational Development 32 (5), 665-673.

Lave, J., 2011. Apprenticeship in Critical Ethnographic Practice. University of Chicago Press, Chicago.

Lim, Z., Anderson, C., McGrath, S., 2012. Professional skills development in a resource-poor setting: the case of pharmacy in Malawi. International Journal of Educational Development 32 (5), 654-664.

Maurice, M., Sellier, F., Silvestre, J., 1986. The Social Foundations of Industrial Power. MIT Press, Cambridge, MA.

McGrath, S., 2010. Beyond aid effectiveness: the development of the South African further education and training college sector, 1994-2009. International Journal of Educational Development 30 (5), 525-534.

McGrath, S., 2012. Vocational education and training for development: A policy in need of a theory? International Journal of Educational Development 32 (5), 623-631. McGrath, S., Badroodien, A., 2006. International influences on the evolution of skills development in South Africa. International Journal of Educational Development 26 (5), 483-494.

McGrath, S., Badroodien, A., Kraak, A., Unwin, L. (Eds.), 2004. Shifting Understandings of Skill. HSRC Press, Cape Town.

McGrath, S., Lugg, R., 2012. Knowing and doing vocational education and training reform: Evidence, learning and the policy process. International Journal of Educational Development 32 (5), 696-708.

Norrag, 2011. Norrag News 46. http://www.norrag.org. Owens, S., Connell, R., 2001. Going crisply to damnation? Challenging the metaphor of the 'toolkit'. EG August/September, 12-14. 
Powell, L., 2012. Reimagining the purpose of VET - Expanding the capability to aspire in South African Further Education and Training students. International

Journal of Educational Development 32 (5), 643-653.

Powell, L., Lolwana, P., 2012. From reconstruction to deconstruction: the role of research in South African skills development. Paper prepared for ADEA 2012

Triennale, Burkina Faso, 12-17 February.

Rogoff, B., Lave, J. (Eds.), 1984. Everyday Cognition. Harvard University Press, Cambridge, MA.

Rose, M., 2004. The Mind at Work. Penguin, New York.

Sennett, R., 2008. The Craftsman. Allen Lane, London.

Sennett, R., 2012. Together. Allen Lane, London.

UNESCO, 2012. World TVET Report. Transforming TVET for Better Learning, Working and Living. UNESCO, Paris.

Walker, M., McLean, M., 2010. Making lives go better: university education and "professional capabilities". South African Journal of Higher Education 24 (5), 847-869.

Walker, M., McLean, M., Dison, A., Peppin-Vaughan, R., 2009. South African universities and human development: towards a theorisation and operationalization of professional capabilities for poverty reduction. International Journal of Educational Development 29 (6), 565-572.

Winch, C., 1998. Two rival conceptions of vocational education: Adam Smith and Friedrich List. Oxford Review of Education 24 (3), 365-378.

Winch, C., 2000. Education, Work and Social Capital. Routledge, London.

Winch, C., 2006. Georg Kerschensteiner: founding the dual system in Germany. Oxford Review of Education 32 (3), 381-396.

World Bank, 1991. Vocational and Technical Education and Training. World Bank, Washington.

Published in International Journal of Educational Development 32 (2012) 619-622 